\title{
Conceptual and methodological aspects in clinical and epidemiologic studies: Contributions to the scientific Field of Food and Nutrition in Brazil
}

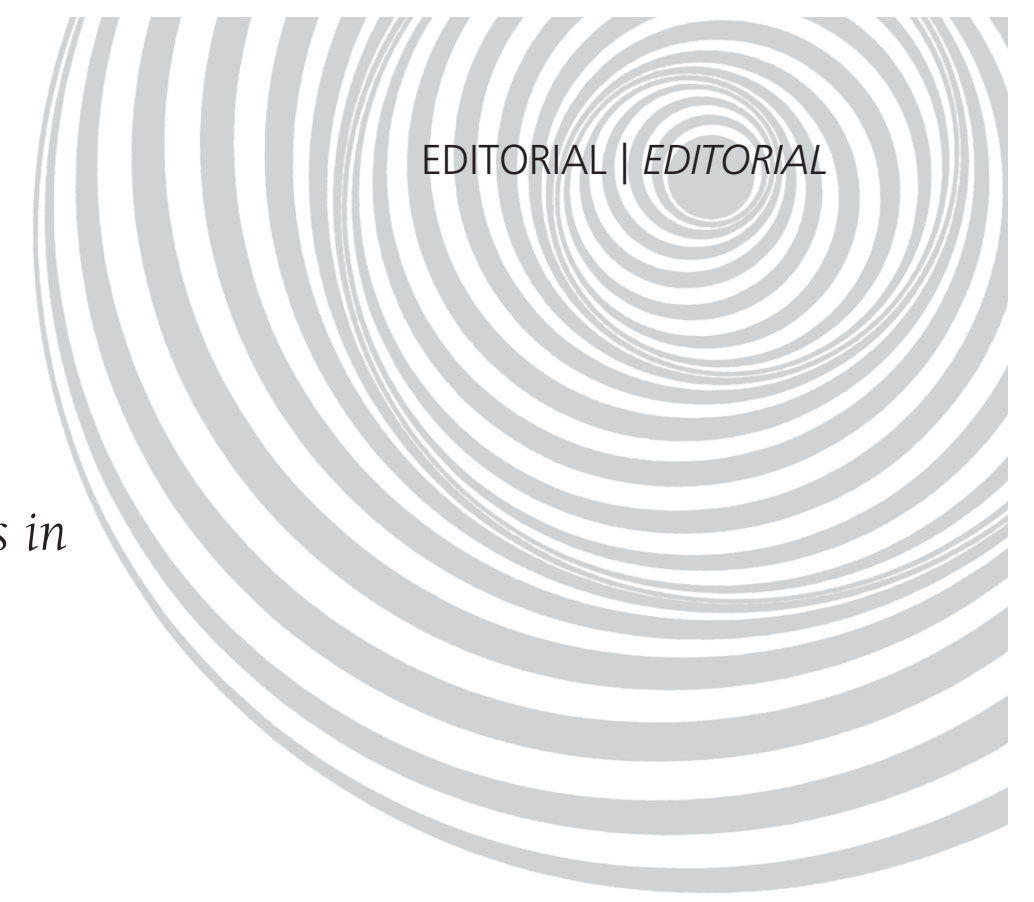

The year of 2006 corresponds to a landmark in the trajectory of the scientific Field of Food and Nutrition in Brazil. Two interconnected events of greater importance deserve to be mentioned at this time.

One of these events was the first meeting of coordinators of graduate programs on Food and Nutrition in Salvador (BA). Eleven of the twelve programs accredited by Coordenação de Aperfeiçoamento de Pessoal de Nível Superior (Capes) were represented. At the time they were part of the Assessment Area Medicine II. Assuming from that time the role of agents determined to participate actively in the construction of a dynamic field in Brazilian science, they follow growing to this day, investing in many fronts. A special emphasis should be given to the organization of seminars inserted in scientific events of the area aiming at the discussion about methodological aspects of studies in the food and nutrition field and their correspondent dissemination in scientific periodicals.

The second event regards the scope of the Journal of Nutrition, which embraces the initiative of the abovementioned group, called Fórum Nacional de Coordenadores de Programas de Pós-Graduação em Alimentação e Nutrição (PPG A\&N, National Forum of Coordinators of Graduate Programs in Food and Nutrition) and, in a partnership that has proven to be profitable and solid, publishes its first Theme Section ${ }^{1}$ in the same year of 2006, disseminating texts created during the meeting in Salvador $(\mathrm{BA})^{2-4}$.

In the year of 2011, the new Theme Section was published when the Assessment Area called "Nutrition" was created ${ }^{5-8}$. This was a historic feat performed by the PPG A\&N Forum, which activated many actors in and out of the Field of Food and Nutrition, coordinating a new solid front in its arguments and political action.

The area of Nutrition in Capes is currently represented by 25 graduate programs: three of them are professional master's degrees, eleven are academic master's degrees, and eleven are academic master's and doctorate degrees. The numerical and qualitative growth is evident, with emphasis on the continuous concern and permanent compromise with the highest pattern in the theoretical and methodological discussions that strengthen this scientific field.

In this sense, partnerships established between the Forum PPG A\&N and the Sociedade Brasileira de Alimentação e Nutrição (SBAN, Brazilian Society of Food and Nutrition) allow the performance of five Methods' Seminars in Graduate programs in food and nutrition organized inside national SBAN congresses between 2007 and 2013. As one of the results of this important group work, the presentations that 
occurred in these events originated two more Theme Sections covering the first events ${ }^{9}$ disseminated in the next two years ${ }^{10-16}$.

Hence, we would like to present four studies presented during the $4^{\text {th }}$ and $5^{\text {th }}$ Seminar of Graduate Methods in Food and Nutrition that occurred during the $11^{\text {th }}$ and $12^{\text {th }}$ National SBAN Congresses in the cities of Natal, Rio Grande do Norte, in May 2012, and in Foz do Iguaçu, Paraná, in August 2013, respectively.

The articles are organized in two groups as a function of the epistemological foundations that guide them. The first set of studies attempts to invite discussions about methodological procedures in Clinical Nutrition studies, studies about food intake and diet quality, about the body composition of obese individuals, and about procedures regarding the cost of obesity in Brazil.

Maintaining its perspective of valuing the interdisciplinarity that identified food and nutrition as a field of practices, certification of professionals and researchers, and production of knowledge, the Coordination of the Forum PPG A\&N could not leave out the conceptual and methodological approaches proper of the Human and Social Sciences perspective. Thus, the second set of studies discusses qualitative research on food and society, and will be published in the next issue of the Journal of Nutrition.

We reiterate our acknowledgments to the Journal of Nutrition and the SBAN for the important contributions for the discussion and scientific record of themes that help to strengthen the scientific field of food and nutrition.

\section{REFERENCES}

1. Medeiros MAT. Revista de Nutrição inaugura seção temática. Rev Nutr. 2006; 19(6):653-4. doi: 10.15 90/S1415-52732006000600001

2. Kac G, Fialho E, Santos SMC, Assis AMO. Panorama atual dos programas de pós-graduação em Nutrição no Brasil. Rev Nutr. 2006; 19(6):785-92. doi: 10.15 90/S1415-52732006000600012
3. Kac G, Fialho E, Santos SMC, Assis AMO. Reflexões do I fórum de coordenadores de programas de pós-graduação em nutrição no Brasil. Rev Nutr. 2006; 19(6):771-84. doi: 10.1590/S1415-527320060 00600013

4. Jordão AA, Diez Garcia RW, Marchini JS. Fator de impacto e pós-graduação stricto sensu em alimentos, nutrição e ciência e tecnologia de alimentos. Rev Nutr. 2006; 19(6):793-802. doi: 10.1590/S1415-52732006000600014

5. Moura EG, Leite JP. Área de Nutrição na Capes. Rev Nutr. 2011; 24(6):801-8. doi: 10.1590/S1415-5 2732011000600001

6. Kac G, Proença RPC, Prado SD. A criação da área "Nutrição" na Capes. Rev Nutr. 2011; 24(6):905-16. doi: 10.1590/S1415-52732011000600011

7. Olinto MTA, Lira PIC, Marchini JS, Kac G. Formação humana, pesquisa e produção científica na subárea de avaliação "Nutrição" da Coordenação de Aperfeiçoamento de Pessoal de Nível Superior, no Brasil, de 2007 a 2009. Rev Nutr. 2011; 24(6):917-26. doi: $10.1590 / 51415-52732011000600012$

8. Prado SD, Bosi MLM, Carvalho MCVS, Gugelmin AS, Mattos RA, et al. Alimentação e Nutrição como campo científico autônomo no Brasil: conceitos, domínios e projetos políticos. Rev Nutr. 2011; 24(6):927-38. doi: 10.1590/S1415-52732011000 600013

9. Kac G, Medeiros MAT. Sobre os métodos da pesquisa em nutrição. Rev Nutr. 2008; 21(6):617-9. doi: 10.1590/S1415-52732008000600001

10. Abdalla DSP, Sena KCM. Biomarcadores de peroxidação lipídica na aterosclerose. Rev Nutr. 2008; 21(6):749-56. doi: 10.1590/S1415-527320080 00600013

11. Fialho E, Moreno FS, Ong TP. Nutrição no pós-genoma: fundamentos e aplicações de ferramentas ômicas. Rev Nutr. 2008; 21(6):757-66. doi: 10.15 90/S1415-52732008000600014

12. Yokoo EM, Pereira RA, Veiga GV, Nascimento S, Costa RS, Marins VMR, et al. Proposta metodológica para o módulo de consumo alimentar pessoal na pesquisa brasileira de orçamentos familiares. Rev Nutr. 2008; 21(6):767-76. doi: 10.1590/S1415-52732008000600015

13. Canesqui AM. Pesquisas qualitativas em nutrição e alimentação. Rev Nutr. 2009; 22(1):125-39. doi: 10.1590/S1415-52732009000100012

14. Santos IS. Avaliação do impacto de programas nutricionais. Rev Nutr. 2009; 22(1):141-50. doi: 10.1590/S1415-52732009000100013 
15. Anjos LA, Souza DR, Rossato SL. Desafios na medição quantitativa da ingestão alimentar em estudos populacionais. Rev Nutr. 2009; 22(1):151-61. doi: 10.1590/S1415-52732009000100014

16. Ribeiro EB. Studying the central control of food intake and obesity in rats. Rev Nutr. 2009;
22(1):163-71. doi: 10.1590/S1415-5273200900 0100015

Rossana da Costa Pacheco PROENÇA
Shirley Donizete PRADO
Kenia Mara Baiocchi de CARVALHO
Ligia AMPARO-SANTOS
1,5

1 Coordenação do Fórum Nacional de Coordenadores de Programas de Pós-Graduação em Alimentação e Nutrição. Brasília, DF, Brasil.

2 Universidade Federal de Santa Catarina, Programa de Pós-Graduação em Nutrição. Florianópolis, SC, Brasil.

${ }^{3}$ Universidade do Estado do Rio de Janeiro, Programa de Pós-Graduação em Alimentação, Nutrição e Saúde, Instituto de

Nutrição. Rio de Janeiro, RJ, Brasil. Correspondência para/Correspondence to: SD PRADO. E-mail:<shirley.prado@yahoo.com.br>.

${ }^{4}$ Universidade de Brasília, Programa de Pós-Graduação em Nutrição Humana. Brasília, DF, Brasil.

${ }^{5}$ Universidade Federal da Bahia, Programa de Pós-Graduação em Alimentos, Nutrição e Saúde. Salvador, BA, Brasil. 
